\section{En tropisk orkan}

Espen Søbye

En mann fra forgangne århundrer

Overlege Johan Scharffenbergs liv og virke

1869-1965. En arkivstudie.

938 s, ill. Oslo: Oktober, 2010.

Pris NOK 499

ISBN 978-82-495-0608-8

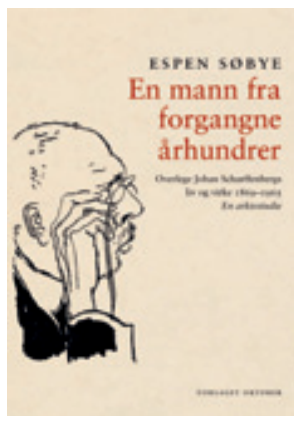

Det er en begivenhet når Espen Søbye utgir en bok. Kanskje litt merkelig, fordi mannens bakgrunn virker nokså tørr: magister i filosofi som i mange år har arbeidet med historisk statistikk

i Statistisk sentralbyrå. Så feil kan man ta. Kritikeren og forfatteren Espen Søbye har gjennom en årrekke markert seg som en av landets skarpeste penner. Han har bl.a. skrevet biografier om Arthur Omre (1992), Rolf Stenersen (1995) og den jødiske jenta Kathe Lasnik (2003) (1). Han er blitt kåret til en av Norges ti fremste intellektuelle (2), og i 2006 ble han valgt til årets litteraturkritiker. Det kan derfor vanskelig karakteriseres som annet enn et lykketreff at Statens institutt for rusmiddelforskning (SIRUS) fikk rekruttert Søbye til å skrive biografien om overlege Johan Scharffenberg (1869-1965).

\section{Frem fra glemmeboken}

I dag er Johan Scharffenberg nærmest glemt. Men i samtiden visste alle hvem han var. Ja, langt mer enn det. Han ble oppfattet som nasjonens våkne samvittighet. Et uttrykk for denne posisjonen var det at han, den gamle republikaner, talte for kongefamilien på Slottsplassen 7. juni 1945.

Etter å ha lest Søbyes bok er det særlig tre ting som slår meg. Det ene er den enorme bredden i Scharffenbergs engasjement. Han var psykiater og fengselslege og la ned et stort arbeid bl.a. ved Oslo Hospitals sinnssykeasyl og Botsfengselet i Oslo og var en hyppig benyttet rettspsykiater. Men dette er likevel bare en liten del av livsverket. Scharffenberg var ustanselig til stede i offentligheten med kronikker, foredrag, bøker og pamfletter. Han deltok $i$ et utall av datidens debatter, kjempet for avholdssaken, forsvarssaken, målsaken og der «det gjaldt kamp for frisinn, for demokrati og sociale reformer, for sannhet og rett», som Otto Lous Mohr skrev om ham (3). Det andre slående poenget er hvor lenge han holdt på. Han publiserte sine første artikler i Romsdals budstikke i 1887, 17 år gammel, og den siste kronikken sto i Morgenbladet i september 1964, da var han nesten 95 år. I tillegg til dette langvarige og brede engasjementet kommer hans nesten ubegripelige energi og arbeidskraft. I de 77 årene han ytret seg i offentligheten, varierte selvsagt strømmen av bidrag, men hele tiden var han i gang, og i lange perioder kan virksomheten «liknes med en tropisk orkan», skriver Søbye (s. 432).

Hvordan kan en sånn mann ha gått i glemmeboken? Et svar får vi vel ved å tenke over hvor få navn vi selv husker fra første halvdel av 1900-tallet. Men nå har Espen Søbye gjort sitt for å rette på det. Og han har gjort det til gagns. Boken er på 851 sider pluss 62 sider noter og et godt navneregister på 20 sider.

\section{Uavhengighet fremfor alt}

Johan Scharffenberg var en ytterst fascinerende person, et komplekst menneske, og enkelte sider av ham minner i påfallende grad om en annen kollega, dr. Stockmann. Han tok feil i mange ting og kunne være sta, stri og urimelig. Johan Borgen hevdet at han var en irriterende mann både for sine motstandere og sine tilhengere. Men et menneske skal jo gjerne vurderes ut fra sine beste egenskaper. «Нøy intelligens, skarp penn og uforlignelige retoriske ferdigheter fenget den allmenne interesse. Hans manuskripter var alltid logiske og gjennomarbeidede og inneholdt gjerne en rekke fakta som gav dem varig verdi og gjorde hans meninger vanskelige å gjendrive», står det i Norsk biografisk leksikon (4).

Et enstemmig presidentskap i Stortinget foreslo i 1947 ærespensjon til Scharffenberg for hans «høitliggende livsgjerning i Norges tjeneste» (3). Han kunne ha god bruk for pengene, hans pensjon var beskjeden. Men Scharffenberg avslo med takk. Han ønsket å stå fritt, uavhengig av alle hensyn. Han ville derfor heller ikke ha noen lederstilling innenfor partier eller organisasjoner. Hans uavhengighet sto over alt annet, hevdet han. Jeg tar meg i å savne en Scharffenberg i vår tid.

\section{Manglende fortellerstemme}

Undertittelen er En arkivstudie. Dette er originalt. I overfloden av materiale som Scharffenberg etterlot seg, har Søbye latt kildene få tale. Som fortellerteknisk grep fungerer det forbausende godt, og boken har fått svært god mottakelse av anmelderne: «mesterverk» (5), «et imponerende arbeid» (6), «et kunstverk» (7) og «intellektuell kraftprestasjon» (8).

Søbye har selv kalt dette et strengt litterært program. Legg frem kildene, så langt de rekker, og la leserne gjøre seg opp sine egne meninger. Selve ideen er god. Det finnes så mange dårlige eksempler på biografier der forfatterstemmen er for påtrengende, der psykologiseringen er amatørmessig eller arbeidet med kildene altfor svakt. Men min hovedinnvending gjelder imidlertid nettopp dette fraværet av fortellerstemme. Problemet er at Søbye her trekker biografien over i den andre grøften. En anmelder skrev at Søbye gjerne kunne «ha skrevet et bind til» (5). Så sant, for Søbye er en glitrende skribent. Problemet er at bind 2 måtte ha blitt et kommentarbind, der Søbye kunne ha utlagt hva han har kommet frem til. Et eksempel på at han ikke helt

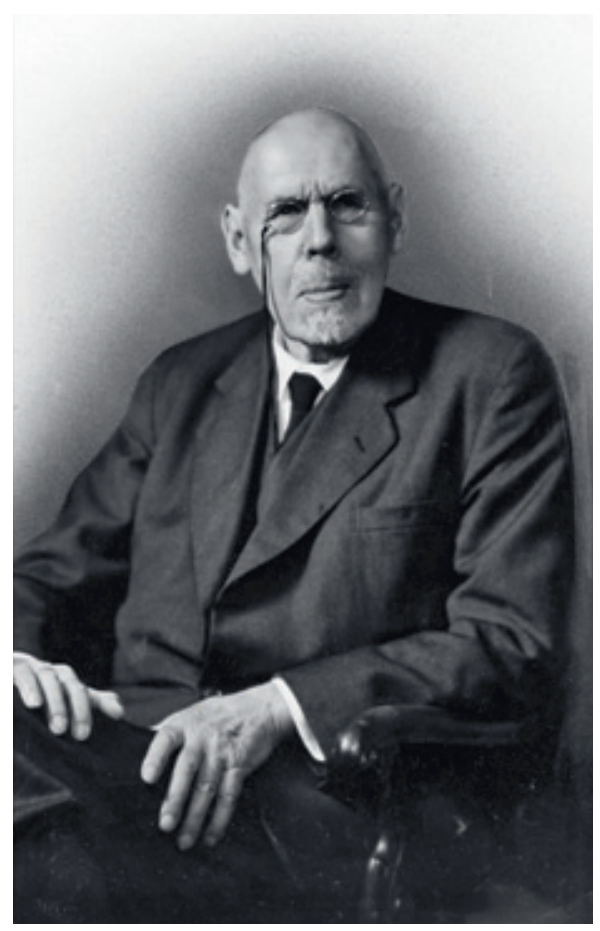

Figur 1 Johan Scharffenberg fotografert i 1959, 90 år gammel. Foto fra Norsk biografisk leksikon, Kunnskapsforlaget (4). () Aschehoug 


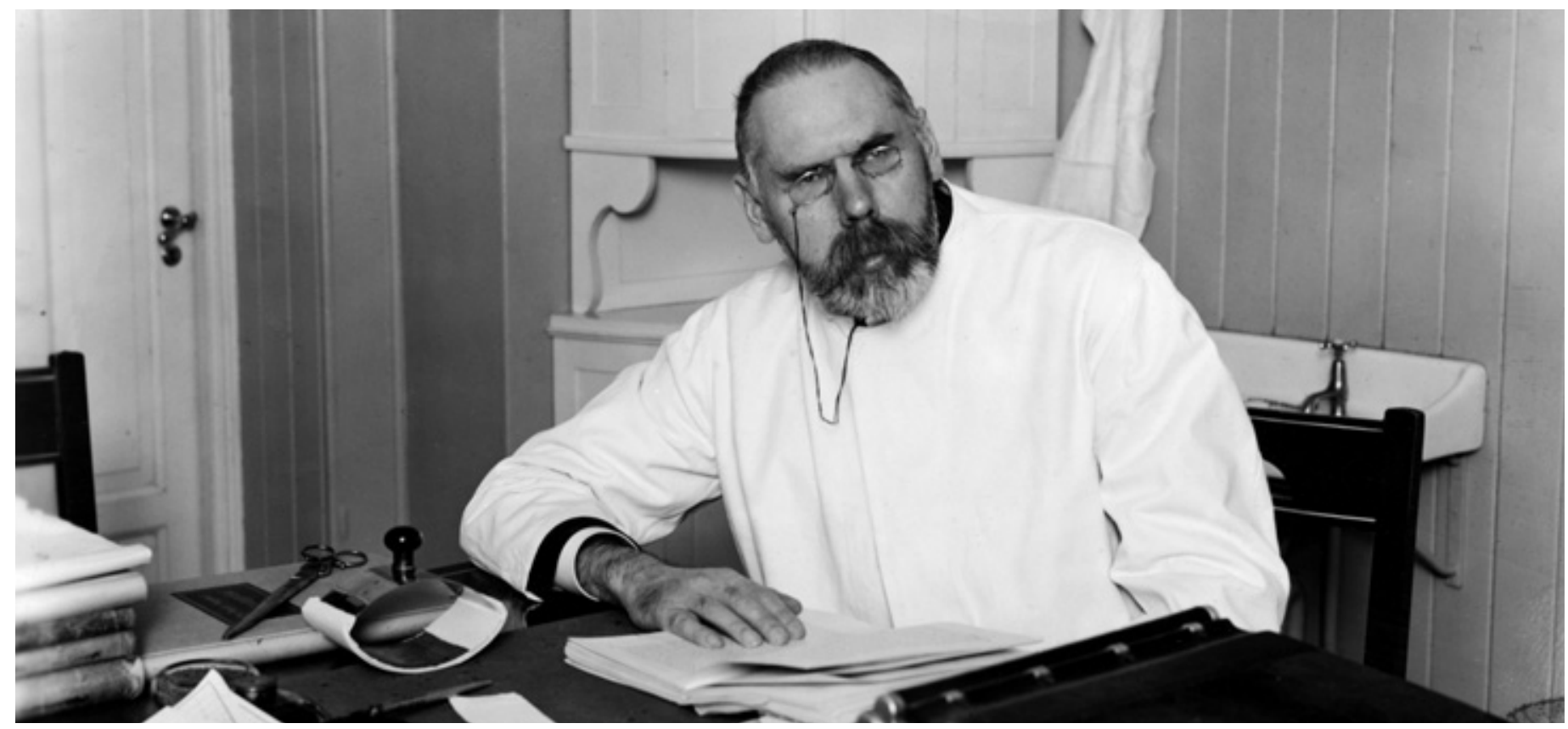

Det eneste kjente fotografiet av Johan Scharffenberg i arbeid som lege. Det er usikkert om det er fra hans kontor i Botsfengselet eller på Oslo asyl. Det er trolig tatt omkring 1935 da Scharffenberg var i midten av 60-årene. Foto SCANPIX

har klart å dy seg, er da medisinstudenten Scharffenberg i 1896 advarte mot overproduksjon av leger. «Det er merkelig,» skriver Søbye, «at Scharffenberg som ellers hevdet at konkurranse førte til utvikling og framskritt, mente at rivalisering mellom leger ville skape dårligere forhold både for legen og pasientene» (s. 143). Jeg skulle ønsket meg flere slike oppsummerende og sammenbindende kommentarer og analyser. Som lesere blir vi rett og slett overlatt for mye til oss selv. Søbyes strenge litterære program kan stå som inspirasjon, men ikke mer. Det er ikke et eksempel til etterfølgelse. Søbye har arbeidet med denne boken i ca. seks år, en formidabel jobb. Men det blir naivt å tro at vi som lesere skal ha samme forutsetninger som forfatteren til å fortolke materialet som presenteres.

Søbyes kildenære metode og manglende forfatterstemme kan gi et inntrykk av objektivitet. Den overveldende stoffmengden og den fortettede stilen gir dessuten en følelse av at alt er med. Slik er det jo ikke - men her gir Søbye ingen veiledning. Det er litt pussig at f.eks. Wiborgsaken ikke er omtalt. Det var en oppsiktsvekkende sak hvor den kjente advokaten Oscar Strøm ble myrdet på åpen gate i Kristiania av iseksportør Axel Wiborg i juni 1914. Den ble bl.a. omtalt i en rekke artikler i Tidsskriftet året etter. Scharffenberg var rettspsykiatrisk sakkyndig, Wiborg ble erklært tilregnelig og dømt til 12 års fengsel i 1915. Wiborg anmeldte Scharffenberg i 1919, men det endte med at påtalemyndigheten ikke ville reise sak.

\section{Ingen å takke?}

Til et slikt kjempeløft som denne boken er, er det merkverdig at det verken finnes forord, etterord eller noen form for takk til hvem som må ha hjulpet til underveis. Riktignok angis det på kolofonsiden åtte institusjoner som har støttet prosjektet økonomisk, og enkelte steder i teksten og notene angir forfatteren hvem han har fått opplysninger fra. Det er også opprørende avsnitt om hvordan Gaustad sykehus tilsynelatende trenerte forfatterens tilgang til Scharffenbergs gamle journaler (9). Men i det store og hele stusser jeg over mangelen på takksigelser. Dette blir desto merkeligere i lys av Søbyes stimulerende beskrivelser av arbeidet med arkivene og arkivaliene. Leserne får her innblikk i deler av tilblivelsen. Men hva med det andre?

\section{Bilderedaktørens ansvar}

Illustrasjonene er fordelt på tre bildelegg på til sammen 48 sider. Bare 18 av bildene er fotografier med Scharffenberg. Hans egenartede utseende gjorde at han sikkert var et yndet objekt blant karikaturtegnere, og flere gode eksempler er gjengitt, men hvorfor er det så få bilder av ham? Og hvilke bestrebelser er gjort for å få tak i bilder? For eksempel er ikke fotografiet som er gjengitt i Norsk biografisk leksikon, med (4) (fig 1). Det blir en påfallende diskrepans mellom den minutiøse omgangen med de skriftlige kildene og den mer likegyldige håndteringen av illustrasjonene. Mistanken om at arbeidet med illustrasjoner er tatt for lett på, styrkes når man leser de nesten intetsigende bildetekstene. De er korte og uinspirerte, f.eks. «København, 1906», og det henvises heller ikke til illustrasjonene i den løpende teksten. Enkelte av illustrasjonene virker også umotiverte, hvorfor er det f.eks. et bilde av «Kongen og kronprinsen ankommer Stortinget, 1930»?

\section{Konklusjon}

Søbyes kanskje største fortjeneste er det utrettelige, nitide og møysommelige arbeidet med kildene. Det er fantastisk at han har funnet helt nytt materiale om en rekke saker som Scharffenberg var involvert i, bl.a. om Scharffenbergs første store feide, angrepet på kirurgiprofessor Julius «Kniven» Nicolaysen (10), som belyses ved omfattende funn fra Oslo politikammers arkiv.

Det er lenge siden jeg har lest en bok med slik appetitt. Jeg anbefaler den varmt til alle med historiske interesser.

\section{Erlend Hem}

erlend.hem@medisin.uio.no

Tidsskriftet

\section{Litteratur}

1. Børdahl PE. En Oslo-pikes liv. Anmeldelse av: Søbye E. Kathe, alltid vært i Norge. Tidsskr Nor Lægeforen 2004; 124: 1815.

2. Godø M. En intellektuell grevling. Dagbladet 16.1.2005. www.dagbladet.no/kultur/2005/01/16/ 420423.html (11.2.2011)

3. Mohr OL. Johan Scharffenberg. I: Jansen E, Svendsen $P$, red. Norsk biografisk leksikon. Bd. 12. Oslo: Aschehoug, 1954: 288-97. Opptrykk i Tidsskr Nor Lægeforen 1965; 85: 485-8.

4. Larsen $\varnothing$. Johan Scharffenberg. I: Arntzen JG, red. Norsk biografisk leksikon. Bd. 8. Oslo: Kunnskapsforlaget, 2004: 60-1. www.snl.no/ .nbl_biografi/Johan_Scharffenberg/utdypning (11.2.2011)

5. Eriksen TB. En myndig og talefør borger. Morgen bladet 12.11.2010: 36-7. www.morgenbladet.no/ apps/pbcs.dll/article?AID=/20101112/OBOKER/ 711129941 (11.2.2011)

6. Hansen J-EE. En mann for sin tid. Aftenposten 14.11.2010: $14-5$.

7. Nilsen H. Livet sett fra arkivet. Klassekampen 20.11.2010: 12-3.

8. Bulie K. Arkivenes herre. Dagens Næringsliv 2.12.2010: 72

9. Ottosen P. - Gaustad trenerte biografien. Dagbladet 6.12.2010: 53 .

10. Hem E. En rettssak som ikke ble noe av. Tidsskr Nor Lægeforen 2006; 126: 1295. 